\title{
Parvovirus B19 infection, hepatitis C virus infection, and mixed cryoglobulinaemia
}

Patrice Cacoub, Narjis Boukli, Pierre Hausfater, Antoine Garbarg-Chenon, Pascale Ghillani, Vincent Thibault, Lucile Musset, Jean Marie Huraux, Jean-Charles Piette

\begin{abstract}
Background-Infection with human parvovirus $B 19$ (B19) has been reported in a few patients with various vasculitis syndromes. Mixed cryoglobulinaemia (MC), a model of small vessel size vasculitis, may result from numerous infectious diseases, particularly hepatitis $\mathrm{C}$ virus $(\mathrm{HCV})$ infection.
\end{abstract}

Aim-To assess the prevalence of seric B19 infection markers in a large series of patients with MC, with or without $\mathrm{HCV}$ infection.

Patients and methods-Sixty four patients were studied: essential MC (EMC, $n=19)$, MC associated with non-infectious diseases (non-essential MC, $\mathrm{n}=9$ ), and patients with $\mathrm{HCV}$ infection with $(\mathrm{HCV}$ MC, $n=18)$ or without MC (HCV-no-MC, $n=18)$. Patients were considered to have MC if two successive determinations of their serum cryoglobulin concentration were above $0.05 \mathrm{~g} / \mathrm{l}$. Serum samples were analysed for specific IgG and IgM antibodies to $B 19$ by enzyme immunoassay. B19 DNA detection was performed by polymerase chain reaction using a set of primers located in the VP1 gene, separately in serum and in cryoprecipitates to investigate a possible capture of B19 DNA in cryoprecipitate. The study also looked for a possible enrichment for of IgG antibodies to B19 in MC.

Results-The presence of specific IgG antibodies to $\mathrm{B} 19$ was found in $68 \% \mathrm{EMC}$, $56 \%$ non-essential MC, $78 \%$ HCV-MC, and $78 \% \mathrm{HCV}-$ no-MC. No patient of either group had specific IgM antibodies to B19, or B19 DNA in serum or in cryoprecipitate. Overall, IgG antibodies to $B 19$ were found in 46 of $64(72 \%)$ serum samples, a prevalence quite similar to the prevalence in general adult population $(>60 \%)$. A specific enrichment of IgG antibodies to $\mathrm{B} 19$ in the MC was not found.

Conclusion-These results suggest that $B 19$ infection is neither an aetiological factor of EMC, nor a cofactor that may lead to MC production in patients with chronic HCV infection.

(Ann Rheum Dis 1998;57:422-424)

Correspondence to: Professor P Cacoub, Department of Internal Medicine, Hôpital La Pitié-Salpêtrière, 83, Boulevard de l'Hôpital, 75651 Paris Cedex 13, France.

Accepted for publication 8 June 1998
Case reports of B19 infection associated with neuropathies, vasculitis or erosive polyarthritis suggest that B19 could be an aetiological factor of some vasculitis syndromes. ${ }^{34}$

The syndrome of mixed cryoglobulinaemia (MC) is characterised by the clinical triad of purpura, arthralgia, and asthenia associated with cryoglobulins composed of different immunoglobulins. ${ }^{5}$ Widespread vasculitis usually involves small and medium size vessels, particularly in the nervous system and in the skin. ${ }^{6} \mathrm{MC}$ has been associated with numerous diseases - autoimmune, non-viral infectious or malignant haematological disorders-but may also occur in their absence and is then called "essential" MC. It has been demonstrated that $60-90 \%$ of patients with previously "essential" MC have serological evidence of hepatitis C virus (HCV) infection, suggesting a causative role of $\mathrm{HCV}^{7-10}$

To investigate the prevalence of serological B19 infection markers in patients with MC, we looked for specific IgG and IgM antibodies to B19, and B19 DNA in serum and cryoprecipitate in a large series of patients with MC, with or without $\mathrm{HCV}$ infection.

\section{Methods}

PATIENTS

We studied 64 French white patients. Nineteen patients aged 52 (3) years (mean (SD)) had a symptomatic MC without underlying disease such as autoimmune, infectious or malignant haematological disorders (group $1=$ essential MC). In group 2, nine patients aged 51 (2) years had a MC associated with a known cause of production (non-essential MC): systemic lupus erythematosus $(n=3)$, malignant hemopathy $(n=3)$, infective endocarditis $(n=2)$, and mediterranean fever $(n=1)$. Groups 3 and 4 included patients with chronic HCV infection. Chronic HCV infection was defined by the presence of alanine aminotransferase activities more than twice the upper limit of normal range, anti-HCV antibodies detected by third generation test (ELISA, RIBA), liver biopsy findings compatible with chronic hepatitis $\mathrm{C}$, and no other cause of liver dysfunction (for example, chronic hepatitis $\mathrm{B}$, autoimmune hepatitis, primary biliary cirrhosis, etc). In group 3, 18 patients aged 50 (3) years had a chronic HCV infection and a symptomatic MC. Patients were considered to have a significant cryoglobulin if they had a minimum serum cryoglobulin concentration of $0.05 \mathrm{~g} / 1$ at two determinations (see methods). In group 4, 18 patients aged 52 (2) years had a chronic $\mathrm{HCV}$ infection without MC. 
Table 1 Distribution of parvovirus B19 infection serological markers in patients with essential MC (group 1), MC with a known cause (group 2), and in patients with chronic hepatitis $C$ virus infection with (group 3) or without MC (group 4)

\begin{tabular}{lllll}
\hline & Group 1 & Group 2 & Group 3 & Group 4 \\
\hline Patient number & 19 & 9 & 18 & 18 \\
Underlying disease & no & miscellaneous & HCV & HCV \\
MC status & + & + & + & - \\
B19 IgG in serum & 13 & 5 & 14 & 14 \\
B19 IgM in serum & 0 & 0 & 0 & 0 \\
B19 DNA in cryoprecipitates & 0 & 0 & 0 & - \\
B19 DNA in serum & 0 & 0 & 0 & 0 \\
\hline
\end{tabular}

$\mathrm{HCV}=$ hepatitis $\mathrm{C}$ virus, $\mathrm{MC}=$ mixed cryoglobulinaemia, $\mathrm{B} 19=$ parvovirus $\mathrm{B} 19$ infection, ${ }^{\star}$ mis cellaneous $=$ autoimmune, infectious or malignant haematological disorders.

\section{STUDY DESIGN}

Cryoglobulins were isolated from serum samples, purified, and characterised by immunoblotting at $37^{\circ} \mathrm{C}$ as previously described. ${ }^{11}$ After immunochemical analysis, cryoglobulins were classified according to Brouet et al ${ }^{12}$ : type I cryoglobulins are single monoclonal immunoglobulins; types II and III are mixed cryoglobulins, composed of different immunoglobulins, with a monoclonal component in type II and only polyclonal immunoglobulins in type III. In this study, all patients with cryoglobulinaemia had type II or type III MC. Anti-HCV antibodies were detected in all patients by third generation tests (ELISA, Ortho and RIBA Chiron, Diagnostic Systems).

After collection at $37^{\circ} \mathrm{C}$, serum samples were kept frozen at $-80^{\circ} \mathrm{C}$ until analysis. Serum samples were then thawed and analysed at $37^{\circ} \mathrm{C}$ for specific $\operatorname{IgG}$ and $\operatorname{IgM}$ antibodies to B19 by enzyme immunoassay (Biotrin International, Lyon, France). B19 DNA detection in serum and cryoprecipitates was performed by polymerase chain reaction using a set of primers located in the VP1 gene (01-376: 5'GTG CTT ACC TGT CTG GAT TGC 3' and 02-377: 5' GCT AAC TTG CCC AGG CTT GT 3'). The 402 bp polymerase chain reaction products were analysed on a $1.5 \%$ agarose gel. After southern blotting, polymerase chain reaction products were hybridised with a DIGdUTP labelled oligonucleotide probe (Probe 2560-2600: 5' AAT ATT AAA AGA TCA TTA TAA TAT TTC TTT AGA TAA TCC CC $3^{\prime}$ ). Positive (at a $10^{-6}$ dilution) and negative controls were systematically included in the polymerase chain reaction.

In patients with MC, we also looked for B19 DNA separately in cryoprecipitate and in serum supernatants, to investigate a possible capture of B19 DNA in the cryoprecipitate alone. In six selected MC patients of different groups - according to the presence of a sufficiently high cryoglobulin concentration (above $0.8 \mathrm{~g} / \mathrm{l}$ ) — we also looked for a possible enrichment of IgG antibodies to B19 in the cryoglobulins. Briefly, we quantified the concentration of IgG in the serum and the cryoprecipitates by nephelometry (BN II Behring, Marbrurg, Germany). Then, we used a quantitative assay for IgG antibodies to B19. Finally, we calculated the ratio: IgG antibodies to $\mathrm{B} 19$ in cryoprecipitate/IgG antibodies to B19 in serum.

Statistical analysis used $\chi^{2}$ or Fisher's exact test for comparisons of percentage. Probability values of less than 0.05 were considered statistically significant.

\section{Results}

Table 1 summarises the distribution of B19 infection markers in the study patients. The presence of specific IgG antibodies to B19 was found in 13 of 19 (68\%) essential MC, 5 of 9 (56\%) non-essential MC, 14 of $18(78 \%)$ HCV-MC, and 14 of 18 (78\%) HCV without MC. However, no patient of either group had specific IgM antibodies to B19, or B19 DNA in serum or in cryoprecipitate. In HCV patients (groups 3 and 4), the prevalence of B19 infection markers was not different whether they have or not MC. In the six selected patients with MC, the ratio IgG antibodies to B19 in cryoprecipitate/IgG antibodies to B19 in serum was from 0.34 to 1.12 .

\section{Discussion}

We found a high prevalence (56 to $78 \%$ ) of IgG antibodies to B19 in patients with MC. However, whatever the aetiology of MC, no patient had IgM antibodies to B19. B19 DNA was not detected in serum or in cryoprecipitates of patients, whatever the group. Also, no MC patient had a serological marker of active B19 infection.

The high prevalence of IgG antibodies to B19 (46 of $64=72 \%$ ) found in serum is not surprising because it is quite similar to the prevalence in general adult population $(>60 \%$ after 50 years). ${ }^{13}$ The prevalence of IgG antibodies to B19 was identical in HCV patients with or without MC. We studied the possibility of false negative results for active B19 infection markers in patients with MC because of B19 DNA capture in cryoprecipitate. We ruled out this hypothesis because when we looked for the presence of B19 DNA separately in serum and in cryoprecipitate, the results remain negative in all cases. We did not find a specific enrichment of IgG antibodies to B19 in cryoprecipitate, suggesting that parvovirus B19 had no role in the MC production.

MC has been associated with numerous diseases - autoimmune, infectious or malignant haematological disorders-but may also occur in their absence and is then called "essential" MC. During acute infections, MC is generally transient and it is rarely symptomatic. MC has been reported with a high frequency in chronic infectious diseases such as subacute bacterial endocarditis, ${ }^{15}$ lepromatous leprosy, ${ }^{16}$ kalaazar, ${ }^{17}$ infectious mononucleosis, ${ }^{18}$ Lyme arthritis, ${ }^{19} \mathrm{HIV}$, cytomegalovirus ${ }^{20}$ and EpsteinBarr virus infection. ${ }^{21}$ All the common hepatitis viruses (A, B, and C) may also lead to the production of MC, but HCV is by far the most frequent infectious aetiological factor. ${ }^{22-24} \mathrm{We}$ and others have demonstrated that more than $70 \%$ of patients with previously "essential" MC have serological evidence of HCV infection, and many data suggest a causative role of $\mathrm{HCV}^{7-10}$ Conversely, MC is particularly frequent in $\mathrm{HCV}$ chronic infection where it is found in up to $60 \%$ of patients. ${ }^{23}{ }^{24}$ However, the search for factors that explain the MC production in these HCV patients is still going on. We previously reported 
that $\mathrm{HCV}$ patients with MC compared with those without MC had a longer duration of $\mathrm{HCV}$ infection and more often liver cirrhosis. ${ }^{10} 25$ The possibility of a HBV coinfection has been ruled out. This study cannot support the hypothesis for a role of a B19 active infection in the mechanisms of MC production either as a single factor in essential $\mathrm{MC}$ or as a cofactor in HCV-MC. A possible link between B19 infection and some vasculitis syndromes have been reported in only a few case reports. ${ }^{46-29}$ However, all the studies searching systematically for markers of B19 active infection in patients with polyarteritis nodosa ${ }^{30}$ or Kawasaki syndrome ${ }^{31} 32$ were negative. Thus, our negative results on B19 infection in MC, a model of small and medium size artery vasculitis, are not surprising.

In conclusion, these results suggest that B19 infection is neither an aetiological factor of essential MC, nor a cofactor that may lead to MC production in patients chronically infected by $\mathrm{HCV}$.

1 Joseph PF. Fifth disease: the frequency of joint involvement in adults. NY State J Med 1986;86:560-83.

Young N. Hematologic and hematopoietic consequences of B19 parvovirus infection. Semin Hematol 1988;25:15972 .

3 Corman LC, Dolson DJ. Polyarteritis nodosa and parvovirus B19 infection. Lancet 1992;339:491.

4 Finkel TH, Torok TJ, Ferguson PJ, Durigon EL, Zaki SR, Leung DYM, et al. Chronic parvorirus B 19 infection and systemic necrotising vasculitis:opportunistic infection or aetiological agent ? Lancet 1994;343:1255-8

5 Meltzer M, Elias K, Mc Cluskey RT, Cooper N, Franklin EC. Cryoglobulinemia: a clinical and laboratory study. Am $\mathrm{J}$ Med 1966;40:837-56.

6 Gorevic PD, Kassab HJ, Levo Y, Kohn R, Meltzer M, Prose $\mathrm{P}$, et al. Mixed cryoglobulinemia: clinical aspects and long term follow-up of 40 patients. Am J Med 1980;69:287308.

7 Agnello V, Chung RT, Kaplan LM. A role for hepatitis C Agnello V, Chung RT, Kaplan LM. A role for hepatitis C
virus infection in type II cryoglobulinemia. N Engl J Med virus infection in

8 Misiani R, Bellavita P, Fenili D, Vicari O, Marchesi D, Sironi $\mathrm{PL}$, et al. Hepatitis C virus infection in patients with essential mixed cryoglobulinemia. Ann Intern Med 1992;117 574-7.

9 Ferri C, Greco F, Longobardo G, Palla P, Moretti A, Marzo $\mathrm{E}$, et al. Antibodies to hepatitis $\mathrm{C}$ virus in patients with mixed cryoglobulinemia. Arthritis Rheum 1991;34:160610. 10 Cacoub P, Lunel-Fabiani F, Musset L, Perrin M, Frangeul virus. Am J Med 1994;96:124-32.

11 Musset L, Diemert M-C, Taibi F, Thi Huong DU L, Cacoub P, Léger JM, et al. Characterization of cryoglobulins by immunoblotting. Clin Chem 1992;38:798-802.
12 Brouet JC, Clauvel JP, Danon F, Klein M, Séligmann M. Biologic and clinical significance of cryoglobulins. Am J Med 1974;57:775-88.

13 Courouce AM, Ferchal F, Morinet F, Muller A, Drouet J, Soulier JP, et al. Human parvovirus infection in France. Lancet 1984;i:160.

14 Cohen BJ, Buckley MM. The prevalence of antibody to human parvovirus B19 in England and Wales. J Med Microbiol 1988;25:151-3.

15 Hurwitz D, Quismorio FP, Friou GJ. Cryoglobulinemia in patients with infectious endocarditis. Clin Exp Immunol 1975;19:131-4.

16 Bonomo L, Dammaco F. Immune complex cryoglobulinemia in lepromatous leprosy. Clin Exp Immunol 1971;9: $175-9$.

17 Most H, Lavietes PH. Kala-azar in american military personnel: report of 30 cases. Medicine 1947;26:221-6.

18 Capra JD, Wingchester RJ, Kunkel HG. Cold reactive rheumatoid factors in infectious mononucloesis and other diseases. Arthritis Rheum 1969;12:67-72.

19 Steere AC, Hardin JA. Ruddy S, Mummaw JG, Malawista SE. Lyme arthritis : correlation of serum and cryoglobulin IgM with activity, and serum IgG with remission. Arthritis Rheum 1979;22:471-7.

20 Kantor GL, Goldberg LS, Johnson BL, Derechin MM, Barnett EV. Immunologic abnormalities induced by postperfusion cytomegalovirus infection. Ann Intern Med 1970;73:553-5

21 Fiorini G, Bernasconi P, Sinico RA, Chianese R, Pozzi F, D'Amico G. Increased frequency of antibodies to ubiquitous viruses in esential mixed cryoglobulinaemia. Clin Exp Immunol 1986;64:65-70.

22 Levo Y, Gorevic PD, Kassab HJ , Zuckler-Franklin D, Fran$\mathrm{klin} \mathrm{EC}$. Association between hepatitis B virus and essential mixed cryoglobulinemia. N Engl J Med 1977;296:1501-4.

23 Lunel F, Musset L, Cacoub P, Frangeul L, Cresta P, Perrin $\mathrm{M}$, et al. Cryoglobulinemia in chronic liver diseases: role of hepatitis C virus and liver damage. Gastroenterology 1994; 106:1291-300.

24 Pawlotsky JM, Ben Hayia M, André C, Voison MC, Intrator $\mathrm{L}$, Roudot-Thoraval F, et al. Immunological disorders in $\mathrm{C}$ virus chronic active hepatitis: a prospective case-control study. Hepatology 1994;19:841-8.

25 Cacoub P, Lunel F, Musset L, Opolon P, Piette JC. Hepatitis $C$ virus and mixed cryoglobulinemia. N Engl J Med 1993;328:1121-2.

26 Nigro G, Zerbini M, Krzysztofiak A, Gentilomi, Poracaro MA, Mango T, et al. Active or recent parvovirus B19 infection in children with Kawasaki disease. Lancet 1994;343: $1260-1$.

27 Tyndall A, Jelk W, Hirsch HH. Parvovirus B19 and erosive polyarthritis. Lancet 1994;343:480-1.

28 Cohen BJ, Buckley MM, Clewley JP, Jones VE, Puttick AH, Jacoby RK. Human parvovirus infection in early rheumatoid and inflammatory arthritis. Ann Rheum Dis 1986;45: 832-8.

29 Naides SJ, Scharosch LL, Foto F, Howard GJ. Rheumatological manifestations of human parvovirus B19 infections in adults. Arthritis Rheum 1990;33:1297-309.

30 Leruez-Ville M, Lauge A, Morinet F, Guillevin L, Deny D. Polyarteritis nodosa and parvovirus B19. Lancet 1994;344: 263-4.

31 Cohen BJ. Human parvovirus B19 infection in Kawasaki disease. [Letter]. Lancet 1994;344:59.

32 Yoto Y, Kudoh T, Haseyama K, Suzuki N, Chiba S. Human parvovirus B19 infection in Kawasaki disease. [Letter]. Lancet 1994;344:58-9. 